\title{
PENGGUNAAN STIMULAN SEJAK AWAL PENYADAPAN UNTUK MENINGKATKAN PRODUKSI KLON IRR 39
}

\author{
Stimulant Application on Early Tapping to Enhance Production of IRR 39 Clone
}

\author{
Island BOERHENDHY \\ Balai Penelitian Sembawa, Pusat Penelitian Karet \\ Jalan Raya Palembang P. Balai Km 29, PO BOX 1127, Palembang 30001
}

Diterima tanggal 14 Mei 2013 / Disetujui 24 Oktober 2013

\begin{abstract}
One of the superior clones in the period of 2010-2014 which has been developed recently is IRR 39 clone. The clone belongs to the group of latex-timber clones with low initial production. An effort made to overcome that weakness is to apply stimulant treatment on early tapping. This article aimed was to provide information on the effect of stimulant application on the early tapping on the production of IRR 39 clone. This trial was conducted at Sembawa Experimental Garden using a randomized completely block design with five treatments and two replications. Application of stimulant since the early tapping had proven that all the treatments of stimulant could increase the production of IRR $39(\mathrm{~g} / \mathrm{t} / \mathrm{t}$ ) as much as $164 \%-181 \%$ of the control. Yield $(\mathrm{kg} / \mathrm{ha} / \mathrm{yr})$ of $\mathrm{S} / 2 \mathrm{~d} 4+$ Ethrel $2 \%$ and $S / 2 d 4+$ Ethrel 2,5\% treatments were lower because the number of tapping days was less than the control. The increased dry rubber yield $(\mathrm{kg} / \mathrm{ha} /$ year) for 7 years' observation was found in S/2 d3 + Ethrel 2,5\% (136\% towards the control) and $S / 2 d 3+$ Ethrel $2 \%$ (123\% towards the control). The treatment $S / 2 d 3+$ Ethrel $2,5 \%$ gave the highest result compared with the other treatments. It was noted that application of stimulant at the beginning of tapping on IRR 39 clone had no negative effects on the growth of girth and bark renewal, dry rubber content as well as tapping panel dryness.
\end{abstract}

Keywords: Hevea brasiliensis, stimulant, early tapping, yield, IRR 39 clone

\footnotetext{
Abstrak

Salah satu klon unggul dalam periode 2010-2014 yang banyak dikembangkan saat ini adalah klon IRR 39. Klon IRR 39 tergolong ke dalam kelompok klon penghasil lateks kayu dengan produksi awal rendah. Salah satu upaya yang dapat dilakukan untuk mengatasi kelemahan tersebut adalah dengan memberikan perlakuan stimulan sejak awal penyadapan. Artikel ini bertujuan untuk memberikan informasi tentang bagaimana pengaruh penggunaan stimulan sejak awal penyadapan untuk peningkatan produksi klon IRR 39.
}

Percobaan dilaksanakan di Kebun Percobaan Balai Penelitian Sembawa menggunakan rancangan acak kelompok (RAK) dengan lima perlakuan aplikasi stimulan dan dua ulangan. Pemberian stimulan sejak awal penyadapan terbukti dapat meningkatkan produksi $(\mathrm{g} / \mathrm{p} / \mathrm{s})$ dari 164 181\% terhadap kontrol. Perlakuan S/2 $\mathrm{d} 4+$ Ethrel $2 \%$ dan $\mathrm{S} / 2 \mathrm{~d} 4+$ Ethrel 2,5\% menghasilkan produksi (kg/ha/th) lebih rendah karena jumlah hari sadap yang lebih sedikit dibanding kontrol. Peningkatan produksi karet kering $(\mathrm{kg} / \mathrm{ha} / \mathrm{th})$ selama 7 tahun pengamatan terdapat pada perlakuan $\mathrm{S} / 2 \mathrm{~d} 3+$ Ethrel 2,5\% (136\% terhadap kontrol) dan S/2 d3 + Ethrel 2\% (123\% terhadap kontrol). Perlakuan $\mathrm{S} / 2 \mathrm{~d} 3+$ Ethrel 2,5\% memberikan hasil lebih tinggi dibandingkan dengan perlakuan lainnya. Penggunaan stimulan sejak awal sadap ternyata tidak berpengaruh negatif terhadap pertumbuhan lilit batang, pertumbuhan kulit pulihan, kadar karet kering, dan kekeringan alur sadap klon IRR 39.

Kata kunci: Hevea brasiliensis, stimulan, awal penyadapan, hasil, klon IRR 39

\section{PENDAHULUAN}

Prospek karet alam ke depan dengan segala dinamikanya masih tetap baik disebabkan pada saat ini suplai pasar karet alam dunia masih terbuka, yang ditunjukkan oleh adanya tren konsumsi yang terus meningkat (Anwar, 2012). Peningkatan konsumsi karet tersebut terutama disebabkan oleh tingginya permintaan dari negara-negara industri karet seperti Amerika, Uni Eropa, Jepang, Cina, India, Rusia, dan Brasilia. Adanya peningkatan pertumbuhan ekonomi global dan kesejahteraan negara-negara di dunia, serta peningkatan harga minyak bumi dan karet sintetis memacu semakin meningkatnya konsumsi karet alam di pasar internasional (IRSG, 2005). 
Kemajuan di bidang pemuliaan karet secara bertahap telah menghasilkan klonklon karet unggul yang sudah cukup luas ditanam secara komersial baik oleh perkebunan besar maupun perkebunan rakyat. Berdasarkan hasil Lokakarya Nasional Pemuliaan Tanaman Karet tahun 2009, rekomendasi untuk bahan tanam karet 2010-2014, diarahkan untuk mendapatkan optimasi hasil lateks maupun kayu (Lasminingsih, 2010).

Pemanfaatan klon unggul sebagai salah satu komponen teknologi telah memberikan proporsi yang besar dalam upaya meningkatkan efisiensi melalui peningkatan produktivitas kebun. Dengan penanaman klon unggul rata-rata produktivitas kebun mencapai 1500-2000 $\mathrm{kg} / \mathrm{ha} / \mathrm{th}$, bahkan untuk klon generasi IV potensi klon bisa mencapai 3500 $\mathrm{kg} / \mathrm{ha} /$ tahun dibandingkan dengan tanaman asal biji (semaian) yang hanya 400 $-500 \mathrm{~kg} / \mathrm{ha} / \mathrm{th}$, dan masa tanaman belum menghasilkan dapat dipersingkat menjadi kurang dari 5 tahun. Oleh karena itu ketersediaan klon unggul merupakan salah satu faktor yang sangat menentukan untuk meningkatkan produktivitas perkebunan karet di Indonesia (Aidi-Daslin, 2005; Woelan et al., 2005).

Salah satu klon unggul dalam periode 2010-2014 yang banyak dikembangkan saat ini adalah klon IRR 39. Klon IRR 39 tergolong ke dalam kelompok klon penghasil lateks kayu (Lasminingsih, 2010). Klon yang termasuk ke dalam kelompok penghasil lateks-kayu secara umum memiliki karakter pertumbuhan cepat (jagur) pada saat tanaman belum menghasilkan (TBM). Hasil pengujian di Kebun Percobaan Sembawa menunjukkan bahwa pertumbuhan lilit batang pada umur 4 tahun (TBM IV) mencapai 48,26 cm dengan laju pertumbuhan sebesar $13,53 \mathrm{~cm} /$ tahun dan setelah tanaman menghasilkan (TM) ratarata sebesar $4,58 \mathrm{~cm} /$ tahun. Ketika tanaman berumur 18 tahun lilit batang dapat mencapai $124 \mathrm{~cm}$. Dengan kondisi demikian maka volume kayu klon IRR 39 pada umur 18 tahun sampai ketinggian $2 \mathrm{~m}$ diatas pertautan okulasi (dpo) diperkirakan sebanyak $0,23 \mathrm{~m}^{3} /$ pohon (Lasminingsih et al., 1998).
Sifat lain yang sangat baik dimiliki oleh klon IRR 39 adalah ketahanannya terhadap penyakit daun Oidium, Colletotrichum, dan Corynespora. Klon IRR 39 mempunyai ketahanan yang baik pula terhadap penyakit kering alur sadap dan jamur upas, serta mempunyai respons yang tergolong sedang terhadap penggunaan stimulan dan ketahanan terhadap angin (Lasminingsih, 2010).

Di samping keunggulan tersebut, klon IRR 39 mempunyai kelemahan produksi pada awal penyadapan. Pada awal penyadapan produksi yang dihasilkan masih relatif rendah, tetapi pada tahap lanjut produksi klon IRR 39 tergolong baik (Lasminingsih, 2010).

Klon unggul yang dihasilkan melalui program pemuliaan ternyata tidak semuanya disadap sesuai dengan sistem eksploitasi yang ada (Junaidi, et al., 1975), sehingga potensi produksi tidak dapat dihasilkan secara optimal. Setiap klon memiliki sifat yang spesifik termasuk klonklon baru yang memiliki produktivitas tinggi, namun sebagian sangat peka terhadap serangan kering alur sadap (KAS), memiliki kulit pulihan yang cenderung benjol-benjol dan kurang respons terhadap pemberian stimulan (Sumarmadji, 2009). Penyadapan yang berlebihan menyebabkan produksi yang berlebihan pada periode awal namun akan diikuti oleh keletihan fisiologis sehingga dalam jangka panjang akan menurunkan produksi. Sebaliknya kekurangan intensitas eksploitasi menyebabkan kapasitas produksi tanaman tidak tergali secara optimal. Akibat dari kedua kondisi tersebut, produktivitas tanaman karet dalam satu siklus ekonomi tidak tercapai secara optimal (Sumarmadji, 2000).

Produksi tanaman karet merupakan hasil resultante dari faktor-faktor: klon, umur tanaman, kerapatan pohon/ha, keadaan agroklimat, pemeliharaan, pemupukan, gangguan penyakit, dan sistem sadap yang digunakan. Untuk mendapatkan produksi tinggi, semua faktor-faktor tersebut harus mendukung. Bila faktorfaktor tersebut tidak memenuhi persyaratan dan secara teknis tidak dilaksanakan dengan baik maka rencana peningkatan 
produksi menjadi sia-sia. Kalaupun terjadi peningkatan produksi, sifatnya hanya sementara kemudian produksi akan menurun kembali (Basuki, 1983).

Produksi awal yang rendah yang dimiliki oleh klon IRR 39 harus diatasi agar potensi hasil klon IRR 39 dapat digali secara optimal. Aplikasi stimulan sejak awal penyadapan diharapkan dapat mengatasi kelemahan tersebut. Menurut Sumarmadji (2009), aplikasi stimulan pada awalnya ditujukan untuk meningkatkan efisiensi penggunaan tenaga penyadap. Pada saat ini sangat banyak produk stimulan yang beredar di pasaran, sehingga berkembang pendapat bahwa untuk meningkatkan produksi harus dilakukan dengan pemakaian stimulan. Hal ini tidak sepenuhnya benar karena pemberian stimulan yang tidak sesuai dengan karakter fisiologis tanaman seringkali menurunkan kesehatan tanaman (Gohet et al., 1969) dan dapat menurunkan produksi (Sumarmadji, 2009).

Stimulan lateks yang sudah umum digunakan untuk tujuan tersebut adalah ethepon dengan nama dagang Ethrel. Stimulan Ethrel mengandung bahan aktif 2chloroethyl-phosphonic acid (ethepon). Bahan ini akan terurai menjadi etilen di dalam jaringan tanaman dan berfungsi untuk meningkatkan tekanan osmotik dan tekanan turgor yang dapat mengakibatkan tertundanya penyumbatan ujung pembuluh lateks sehingga memperpanjang masa pengaliran lateks (Boatman, 1968).

Pemakaian stimulan ethepon dapat meningkatkan hasil lateks secara nyata (Sivakumaran et al., 1984). Namun besarnya respons tanaman karet terhadap stimulan ethepon antara lain bergantung pada jenis klon (Pusat Penelitian Karet, 1993), umur tanaman karet (Webster dan Baulkwill, 1989). konsentrasi stimulan (Junaidi dan Kuswanhadi, 1998), dan sistem sadap terutama intensitas sadapnya (Basuki dan Tobing, 1980).

Artikel ini bertujuan untuk memberikan informasi tentang bagaimana pengaruh penggunaan stimulan sejak awal penyadapan untuk peningkatan produksi klon IRR 39.

\section{BAHAN DAN METODE}

Percobaan dilaksanakan di Kebun Percobaan Balai Penelitian Sembawa, jenis tanah podsolik merah kuning, tinggi tempat $10 \mathrm{~m}$ diatas permukaan laut (dpl), dan curah hujan rata-rata $2267 \mathrm{~mm} / \mathrm{th}$. Penelitian dimulai Mei 2005 sampai Desember 2011, menggunakan klon IRR 39 tahun tanam 1999/2000 dengan jarak tanam 6 m x 3 m (populasi 555 pohon/ha). Rancangan yang digunakan adalah rancangan acak kelompok (RAK) dengan lima perlakuan aplikasi stimulan dan dua ulangan. Pelumasan stimulan lateks dilakukan pada alur sadap (groove application = ga), yaitu dengan cara mengoles stimulan lateks sebanyak 0,5 g/p/aplikasi. Aplikasi dilakukan pada bidang sadap BO- 1 pada 5 tahun pertama dan BO-2 pada periode selanjutnya setiap 15 hari sekali ( 2 kali per bulan) sebanyak 18 kali per tahun. Perlakuan stimulan lateks adalah sebagai berikut: (1) S/2 d3 + Ethrel 2\%, (2) S/2 d4 + Ethrel 2\%, (3) S/2 d3 + Ethrel 2,5\%, (4) S/2 d4 + Ethrel 2,5 \%, dan (5) Kontrol (tanpa perlakuan stimulan dengan sistem sadap $\mathrm{S} / 2 \mathrm{~d} 2$. Jumlah sampel sebanyak 30 pohon untuk setiap perlakuan dan setiap ulangan, sehingga total tanaman yang digunakan adalah 300 pohon. Tanaman dipupuk secara teratur dua kali setahun sesuai anjuran Balai Penelitian Sembawa.

Parameter yang diamati terdiri atas produksi karet kering (lateks dan lum), kadar karet kering lateks, pertumbuhan lilit batang, pertumbuhan kulit pulihan, dan intensitas kering alur sadap. Pengamatan produksi dilakukan sesuai hari sadap berdasarkan perlakuan yaitu $\mathrm{S} / 2 \mathrm{~d} 2, \mathrm{~S} / 2$ d3, dan S/2 d4 yaitu lebar irisan setengah spiral (lingkaran), dilakukan setiap 2 hari, 3 hari, dan 4 hari sekali. Dengan mengetahui produksi karet kering $\mathrm{g} / \mathrm{p} / \mathrm{s}$, jumlah hari sadap per tahun, dan jumlah pohon dapat diketahui produksi per tahun (kg/ha/ tahun), seperti pada rumus berikut:

$$
\begin{aligned}
& \text { Produksi kg/ha/th }=\frac{\text { jumlah pohon per ha }}{1000} \times \text { HSE } \\
& \text { dengan } \mathrm{HSE}=\text { hari sadap efektif }
\end{aligned}
$$

Hari sadap efektif untuk satu tahun (HSE) adalah sebagai berikut: d2 (150 hari), d3 (113 hari), dan d4 (75 hari). Jumlah pohon per hektar adalah 500 pohon (1 hanca). Pengamatan produksi baru dimulai 
pada Tanaman Menghasilkan (TM)2, sedangkan data produksi (kg/ha/th) Tanaman Menghasilkan (TM) 1 merupakan data sekunder diperoleh dari kebun yang dikumpulkan selama satu tahun penyadapan. Pengukuran lilit batang dan pertumbuhan kulit pulihan dilakukan pada awal percobaan dan diulang setiap tahun hingga akhir percobaan. Lilit batang diukur pada ketinggian $1,0 \mathrm{~m}$ dpo, dengan menggunakan meteran kain.

Kadar karet kering (KKK) diukur dengan cara mengambil sebanyak 5-10 gram lateks dari setiap ulangan dan setiap perlakuan. Kemudian lateks tersebut dimasukkan ke dalam cawan aluminium, setelah dibubuhi asam format secukupnya dan diaduk sampai menggumpal sempurna. Gumpalan karet yang diperoleh digiling dengan menggunakan gilingan tangan (hand mangel) hingga membentuk lembaran dengan ketebalan sekitar $1 \mathrm{~mm}$. Lembaran karet kemudian dikeringkan dalam oven pada suhu $110^{\circ} \mathrm{C}$ selama 3-4 jam. Setelah lembaran karet terlihat kering merata lalu didinginkan, selanjutnya ditimbang dengan menggunakan timbangan Dial-0-gram. Dengan membandingkan bobot kering karet terhadap bobot contoh lateks (basah), KKK lateks dan lum mangkuk dapat diketahui.

Untuk mengetahui besarnya intensitas serangan KAS dilakukan dengan cara penyadapan. Dari aliran lateks lima menit pertama dapat diperoleh intensitas KAS (Siswanto dan Darusamin, 1995) (Tabel 1).

\section{HASIL DAN PEMBAHASAN}

\section{Produksi Karet Kering (g/p/s) dan (kg/ha/tahun)}

Produksi kumulatif atau rata-rata $\mathrm{g} / \mathrm{p} / \mathrm{s}$ selama periode pengamatan ditampilkan pada Gambar 1. Gambar 1 memperlihatkan bahwa rata-rata produksi karet kering $(\mathrm{g} / \mathrm{p} / \mathrm{s})$ selama 7 tahun pengamatan menunjukkan perlakuan $\mathrm{S} / 2$ d3 + Ethrel 2,5\% memberikan hasil tertinggi, kemudian diikuti oleh perlakuan $\mathrm{S} / 2 \mathrm{~d} 4+$ Ethrel 2\%, S/2 d4 + Ethrel 2,5\%, S/2 d3 + Ethrel 2\%, dan Kontrol. Secara kumulatif selama 7 tahun pengamatan semua perlakuan stimulan meningkatkan produksi (g/p/s) antara 164 - 181\% terhadap kontrol.

Rata-rata peningkatan produksi karet kering $(\mathrm{g} / \mathrm{p} / \mathrm{s})$ selama 7 tahun pengamatan adalah sebagai berikut: (1) S/2 d3 + Ethrel $2,5 \%(181 \%) ;(2) \mathrm{S} / 2 \mathrm{~d} 4$ + Ethrel $2 \%$ (171\%); (3) S/2 d4 + Ethrel 2,5\%, (164\%); (4) S/2 d3 + Ethrel 2\% (164\%) terhadap kontrol.

Rata-rata produksi karet kering (kg/ha/tahun) selama 5 dan 7 tahun aplikasi Ethrel disajikan pada Tabel 2. Pada saat TM 2 produksi $(\mathrm{kg} / \mathrm{ha} / \mathrm{th})$ tanpa stimulan (kontrol) ternyata sangat rendah yaitu hanya $628,46 \mathrm{~kg} / \mathrm{ha} /$ tahun. Namun sejalan dengan bertambahnya umur tanaman, produksi semakin meningkat. Mulai TM 3 hingga TM 8 produksi yang diperoleh bila tanpa pemakaian stimulan sudah berada di atas $1000 \mathrm{~kg} / \mathrm{ha} /$ tahun, yaitu dengan kisaran 1524,33 - 2054,133 $\mathrm{kg} / \mathrm{ha} / \mathrm{th}$. Secara kumulatif rata-rata produksi karet kering bila tanpa aplikasi stimulan selama 7 tahun pengamatan adalah sebesar 1586,91 kg/ha/th. Produksi karet kering pada tahun pertama sebelum dilakukan pengamatan aplikasi Ethrel adalah $513 \mathrm{~kg} / \mathrm{ha} /$ tahun.

Produksi klon IRR 39 tergolong ke dalam kelompok klon produksi awal rendah yaitu kurang dari $1000 \mathrm{~kg} / \mathrm{ha} / \mathrm{th}$. Produksinya akan terus meningkat sejalan dengan umur tanaman dan akan mencapai optimal saat penyadapan pada kulit pulihan yaitu ketika tanaman berumur antara 15 20 tahun (Azwar dan Suhendry, 1998; Lasminingsih, 2010).

Tabel 1. Intensitas KAS pada lima menit pertama setelah sadap

Table 1. Intensity of tapping panel dryness in the first five minutes after tapping

\begin{tabular}{clc}
\hline No & \multicolumn{1}{c}{$\begin{array}{c}\text { Gejala Tampak setelah lima menit pertama } \\
\text { Symptoms appear after the first five minutes }\end{array}$} & $\begin{array}{c}\text { Intensitas } \\
\text { Intensity } \\
(\%)\end{array}$ \\
\hline 1 & Seperempat alur tidak mengeluarkan lateks & 25 \\
2 & Setengah bagian alur tidak mengeluarkan lateks & 50 \\
3 & Tiga perempat bagian alur tidak mengeluarkan lateks & 75 \\
4 & Seluruh alur tidak mengeluarkan lateks & 100 \\
\hline
\end{tabular}




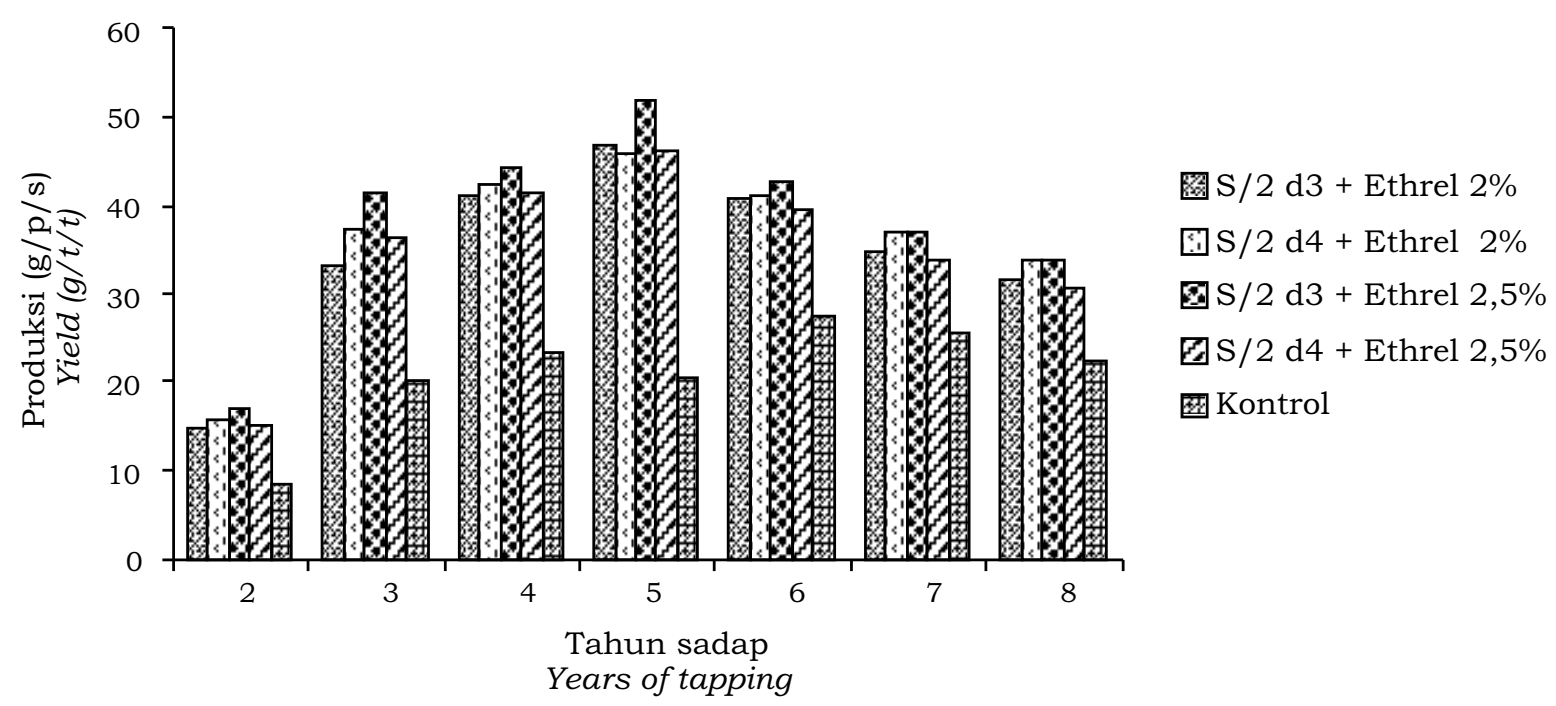

Gambar 1. Produksi karet kering $(\mathrm{g} / \mathrm{p} / \mathrm{s})$ selama 7 tahun pengamatan

Figure 1. Dry rubber production $(g / t / t)$ for seven years' experiment

Pemberian stimulan sejak awal penyadapan terbukti dapat meningkatkan produksi (g/p/s) klon IRR 39. Namun, karena perbedaan jumlah hari sadap, produksi karet kering/ha/tahun untuk perlakuan $\mathrm{S} / 2 \mathrm{~d} 4+$ Ethrel $2 \%$ dan $\mathrm{S} / 2 \mathrm{~d} 4+$ Ethre1 2,5\% tidak menunjukkan peningkatan terhadap kontrol. Peningkatan produksi karet kering $(\mathrm{kg} / \mathrm{ha} / \mathrm{th})$ selama 7 tahun pengamatan terdapat pada perlakuan $\mathrm{S} / 2 \mathrm{~d} 3+$ Ethrel 2,5\% (136\% terhadap kontrol) dan S/2 d3 + Ethrel 2\% (123\% terhadap kontrol). Perlakuan S/2 d3 + Ethrel $2,5 \%$ memberikan hasil terbaik dibandingkan dengan perlakuan lainnya.
Hubungan antara respons umur tanaman terhadap stimulan ethepon bergantung pada umur tanaman, bertambah tua umur tanaman akan bertambah baik pula responsnya. Pada umumnya respons terhadap stimulan ethepon selama penyadapan pada bagian pertama dari panel bawah perawan (BO-1) umumnya tidak baik, pada bidang sadap bagian kedua dari panel bawah perawan (BO-2) relatif lebih baik. Respons yang terbaik diperoleh selama penyadapan dilakukan mulai pada bidang sadap bagian pertama dari panel bawah pulihan pertama (BI-1) dan seterusnya hingga bagian kedua dari panel atas pulihan pertama (HI-2) (Siagian dan Harahap, 1975).

Tabel 2. Rata-rata produksi karet kering/ha/tahun

Table 2. Average dry rubber yield/ha/year

\begin{tabular}{|c|c|c|c|c|c|c|c|c|c|c|}
\hline \multirow{2}{*}{ No } & \multirow{2}{*}{$\begin{array}{l}\text { Perlakuan } \\
\text { Treatments }\end{array}$} & \multicolumn{7}{|c|}{$\begin{array}{l}\text { Produksi tahun sadap }(\mathrm{kg} / \mathrm{ha} / \mathrm{th}) \\
\text { Yield at tapping years }(\mathrm{kg} / \mathrm{ha} / \mathrm{yr})\end{array}$} & \multirow{2}{*}{$\begin{array}{l}\text { Produksi } \\
\text { rata-rata } \\
5 \text { tahun } \\
\text { Average } \\
\text { yield for } \\
5 \text { years }\end{array}$} & \multirow{2}{*}{$\begin{array}{l}\text { Produksi } \\
\text { rata-rata } \\
7 \text { tahun } \\
\text { Average } \\
\text { yield for } \\
7 \text { years }\end{array}$} \\
\hline & & 2 & 3 & 4 & 5 & 6 & 7 & 8 & & \\
\hline 1 & $\mathrm{~S} / 2 \mathrm{~d} 3+\mathrm{E} 2 \%$ & $\begin{array}{r}832,10 \\
(132)\end{array}$ & $\begin{array}{r}1862,26 \\
(122)\end{array}$ & $\begin{array}{l}2325,5 \\
8(133)\end{array}$ & $\begin{array}{l}2644,6 \\
0(172)\end{array}$ & $\begin{array}{l}2301,9 \\
2(112)\end{array}$ & $\begin{array}{c}1953,5 \\
5(102)\end{array}$ & $\begin{array}{c}1772,7 \\
5(105)\end{array}$ & $\begin{array}{r}1993,29 \\
(133)\end{array}$ & $\begin{array}{r}1956,11 \\
(123)\end{array}$ \\
\hline 2 & $\mathrm{~S} / 2 \mathrm{~d} 4+\mathrm{E} 2 \%$ & $\begin{array}{r}599,72 \\
(95)\end{array}$ & $\begin{array}{r}1396,33 \\
(92)\end{array}$ & $\begin{array}{r}1587,8 \\
7(91)\end{array}$ & $\begin{array}{r}1713,5 \\
3(111)\end{array}$ & $\begin{array}{r}1536,8 \\
3(75)\end{array}$ & $\begin{array}{r}1387,7 \\
5(72)\end{array}$ & $\begin{array}{r}1267,7 \\
5(75)\end{array}$ & $\begin{array}{r}1366,86 \\
(91)\end{array}$ & $\begin{array}{r}1355,68 \\
(85)\end{array}$ \\
\hline 3 & $\mathrm{~S} / 2 \mathrm{~d} 3+\mathrm{E} 2,5 \%$ & $\begin{array}{r}955,06 \\
(152)\end{array}$ & $\begin{array}{r}2347,27 \\
(154)\end{array}$ & $\begin{array}{l}2492,9 \\
9(143)\end{array}$ & $\begin{array}{l}2925,4 \\
8(190)\end{array}$ & $\begin{array}{l}2400,6 \\
5(117)\end{array}$ & $\begin{array}{l}2086,9 \\
4(108)\end{array}$ & $\begin{array}{l}1906,1 \\
4(113)\end{array}$ & $\begin{array}{r}2224,29 \\
(148)\end{array}$ & $\begin{array}{r}2159,22 \\
(136)\end{array}$ \\
\hline 4 & $\mathrm{~S} / 2 \mathrm{~d} 4+\mathrm{E} 2,5 \%$ & $\begin{array}{r}560,77 \\
(89)\end{array}$ & $\begin{array}{r}1363,93 \\
(89)\end{array}$ & $\begin{array}{r}1553,7 \\
4(89)\end{array}$ & $\begin{array}{l}1739,0 \\
2(113)\end{array}$ & $\begin{array}{r}1485,1 \\
3(72)\end{array}$ & $\begin{array}{r}1272,7 \\
5(66)\end{array}$ & $\begin{array}{r}1152,7 \\
5(68)\end{array}$ & $\begin{array}{r}1340,52 \\
(89)\end{array}$ & $\begin{array}{r}1304,01 \\
(82)\end{array}$ \\
\hline 5 & Kontrol (S/2d2) & $\begin{array}{r}628,46 \\
(100)\end{array}$ & $\begin{array}{r}1524,33 \\
(100)\end{array}$ & $\begin{array}{l}1745,0 \\
3(100)\end{array}$ & $\begin{array}{l}1542,0 \\
3(100)\end{array}$ & $\begin{array}{l}2054,1 \\
3(100)\end{array}$ & $\begin{array}{l}1924,4 \\
6(100)\end{array}$ & $\begin{array}{l}1684,4 \\
6(100)\end{array}$ & $\begin{array}{r}1498,80 \\
(100)\end{array}$ & $\begin{array}{r}1586,13 \\
(100)\end{array}$ \\
\hline
\end{tabular}

Angka dalam kurung merupakan persentase peningkatan produksi terhadap kontrol

Figures in brackets are the percentage of yield increase compared with the control 
Respons tanaman karet terhadap stimulan ethepon bergantung pula kepada sistem sadap, terutama intensitas sadapnya. Respons yang lebih baik akan diperoleh jika intensitas sadapnya rendah (Basuki dan Tobing, 1980). Pengurangan intensitas sadap dapat dicapai dengan mengurangi frekuensi. Dengan intensitas sadap rendah yaitu dari 2 hari sekali (d2) menjadi 3 hari sekali (d3) atau 4 hari sekali (d4), maka respons klon terhadap stimulan akan menjadi lebih lama (Lukman, 1979).

\section{Kadar Karet Kering (\%)}

Hasil pengamatan kadar karet kering (KKK) $\quad$ TM 2 hingga TM $8 \quad(7$ tahun pengamatan) ditampilkan pada Gambar 2. Rata-rata KKK selama 7 tahun pengamatan bervariasi antara $31,69 \%-35,63 \%$. Secara keseluruhan rata-rata nilai kadar karet kering pada perlakuan dengan stimulan terlihat lebih rendah dibandingkan dengan kontrol (tanpa perlakuan stimulan). Namun, penggunaan stimulan selama 7 tahun penyadapan belum berdampak buruk terhadap nilai KKK, karena secara umum masih berada di atas 30\%. Dilaporkan oleh Karyudi dan Lukman (1985), nilai KKK harus diwaspadai apabila sudah berada di bawah $25 \%$. Untuk mengatasi turunnya KKK lateks dapat dilakukan dengan menurunkan intensitas sadap dan mengurangi pemakaian stimulan.
Pemakaian stimulan ethepon dapat menurunkan persentase kadar karet kering (Basuki dan Lubis, 1973; Siregar et al., 1973; Sumarno et al., 1976). Hal ini dapat terjadi bila dilakukan dengan intensitas sadap tinggi dan dengan konsentrasi ethepon yang tinggi (Lukman, 1979). Menurut Southorn (1969), pemberian stimulan akan menaikkan tekanan turgor pada batang sehingga air yang ada pada jaringan sekitarnya merembes ke dalam pembuluh lateks, dan akhirnya kadar karet keringnya menjadi rendah.

\section{Pertumbuhan Lilit Batang (cm)}

Hasil pengamatan pertumbuhan lilit batang sejak TM 2 hingga TM 8 (7 tahun pengamatan) ditampilkan pada Gambar 3 . Dari Gambar 3 terlihat bahwa pertumbuhan lilit batang bervariasi antara $76,90-86,43 \mathrm{~cm}$. Penggunaan stimulan selama 7 tahun penyadapan tampaknya tidak menghambat pertumbuhan lilit batang. Dilaporkan oleh Lukman (1979), pemakaian stimulan ethepon yang dilakukan pada tanaman muda dapat menghambat pertumbuhan lilit batang. Namun kondisi tersebut dapat terjadi bila dilakukan dengan intensitas sadap tinggi dan disertai alur sadap yang panjang (Basuki dan Tobing, 1980). Oleh karena itu, untuk mengurangi dampak negatif tersebut perlu dilakukan pemupukan yang teratur, pengurangan intensitas sadap dan panjang alur sadap (Lukman, 1979).

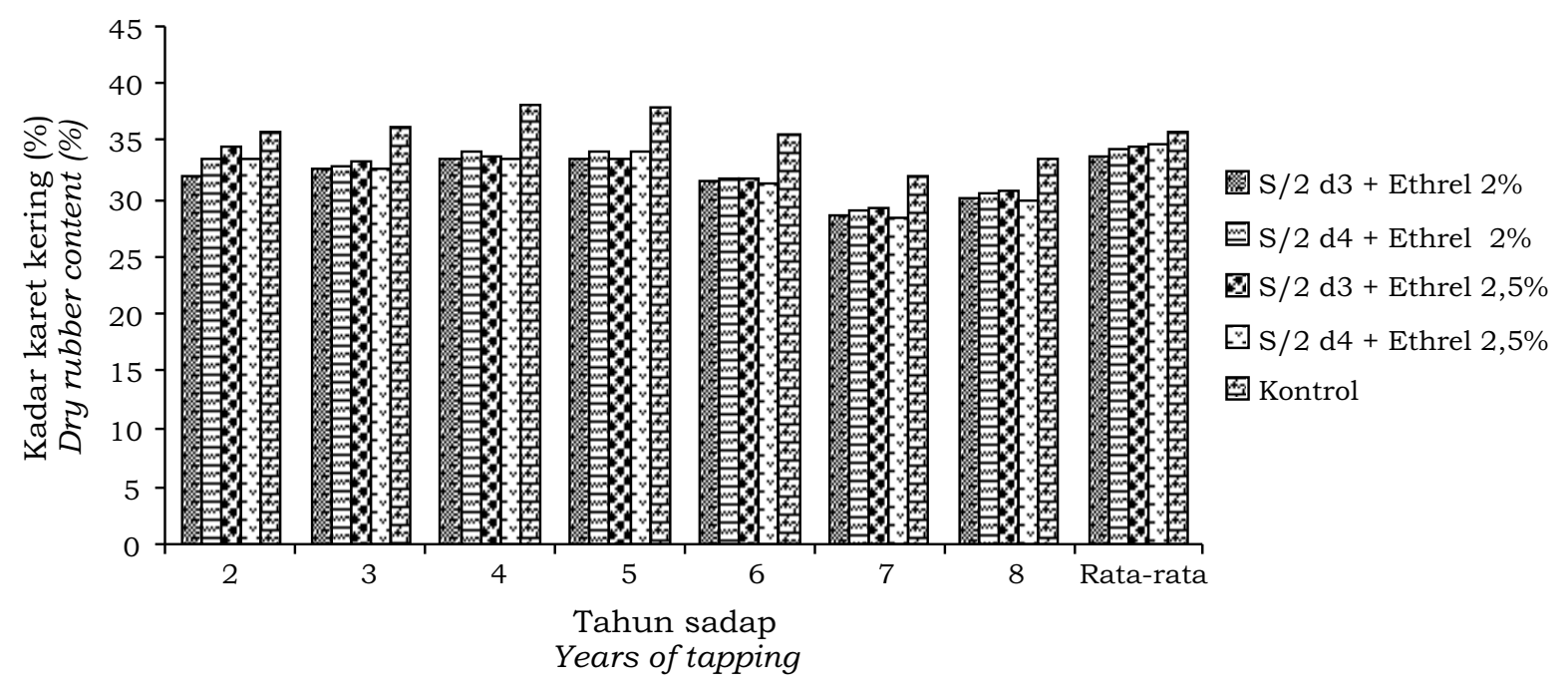

Gambar 2. Persentase KKK lateks klon IRR 39 selama 7 tahun pengamatan Figure 2. Percentage of latex DRC of IRR 39 clone for 7 years' experiment 


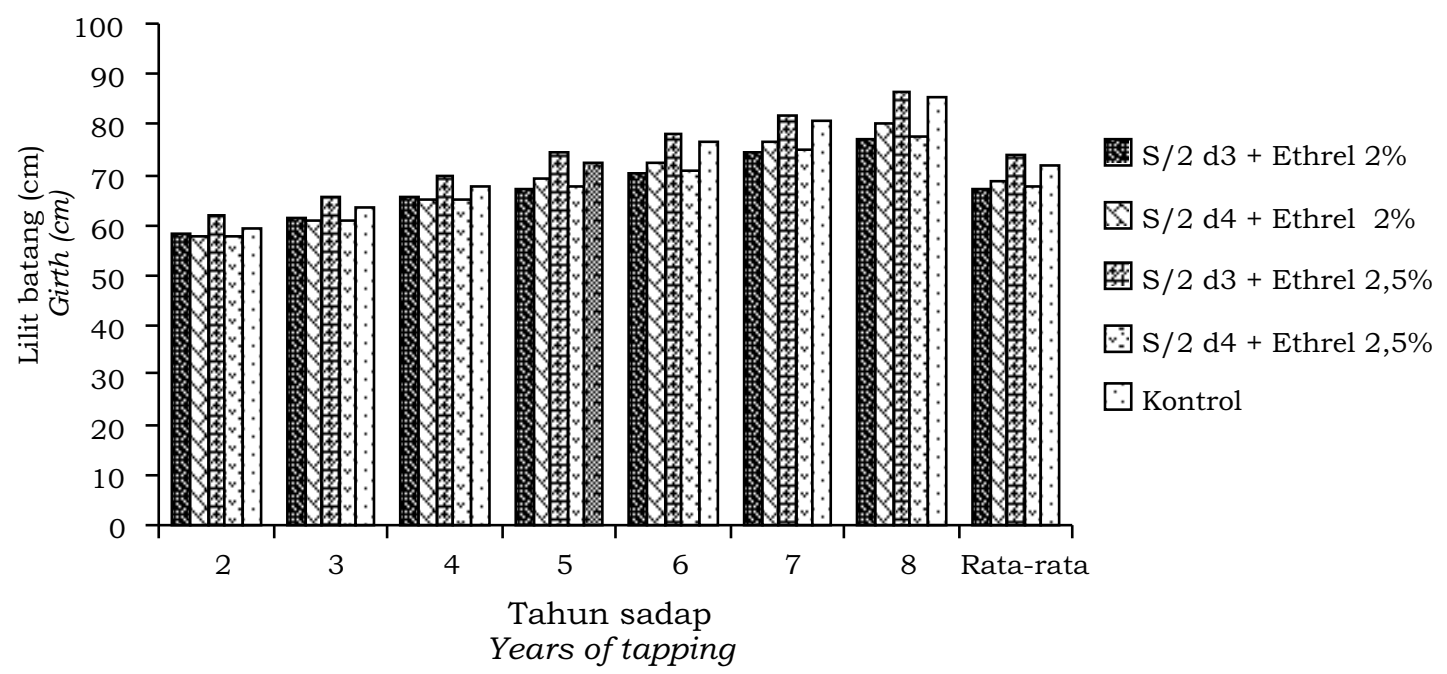

Gambar 3. Pertumbuhan lilit batang $(\mathrm{cm})$ selama tujuh tahun pengamatan

Figure 3. The girth growth $(\mathrm{cm})$ during 7 years of experiment

\section{Pertumbuhan Tebal Kulit (mm)}

Tebal kulit batang juga merupakan salah satu tolok ukur untuk memilih klon yang baik. Parameter pertumbuhan kulit batang sangat penting diketahui bagi tanaman karet. Hal ini disebabkan persediaan lateks hampir sebagian besar tersimpan dalam pembuluh lateks pada kulit batang tanaman. Secara teoritis semakin tebal kulit batang akan semakin banyak saluran pembuluh lateks sehingga produksi yang diperoleh akan semakin tinggi. Namun pada kenyataan antara ketebalan kulit dengan produksi tidak selalu berkorelasi positif. Hal ini kemungkinan terkait dengan sifat dari setiap klon.

Hasil pengamatan terhadap pertumbuhan tebal kulit perawan pada umur 24 bulan, 36 bulan, 48 bulan, 60 bulan adalah sebagai berikut: $3,10 \mathrm{~mm}, 5,13$ $\mathrm{mm}, 7,48 \mathrm{~mm}, 7,64 \mathrm{~mm}$. Berdasarkan kriteria tersebut pada umur 48 bulan tanaman telah siap untuk disadap karena telah mencapai tebal kulit normal untuk buka sadap. Pada percobaan ini menunjukkan bahwa, pertumbuhan kulit pulihan pada bidang sadap BO- 1 bervariasi antara 5,93-6,78 $\mathrm{mm}$, sedangkan pada bidang sadap BO-2 antara 7,31-7,66 mm. Pemakaian stimulan sejak pengamatan (TM 2) atau pada tanaman muda hingga TM $8(7$ tahun pengamatan) tampaknya tidak menghambat pertumbuhan kulit.

\section{Kekeringan Alur Sadap (\%)}

Hasil pengamatan kekeringan alur sadap (KAS) sebagai akibat pemakaian stimulan sejak awal pengamatan (TM 2) hingga TM 8 (7 tahun pengamatan) ditampilkan pada Tabel 3. Dari Tabel 3 terlihat bahwa persentase kekeringan alur sadap akibat pemakaian stimulan bervariasi namun masih tergolong rendah. Dari 30 pohon contoh yang diamati untuk setiap perlakuan ternyata hanya sekitar 2-4 pohon (7-10\%) yang terserang KAS total. Hal ini disebabkan intensitas penyadapan dan pemakaian stimulan masih sesuai anjuran. Menurut Karyudi dan Lukman (1985) pemakaian stimulan pada bidang sadap bawah disarankan dilakukan dengan sistem alur sadap (groove) dengan konsentrasi 2,5\% dan intensitas sadap rendah atau setiap 3 hari sekali (d3).

Dengan cara seperti ini diharapkan dampak pemakaian stimulan terhadap kekeringan alur sadap akan lebih kecil. Rendahnya intensitas serangan kekeringan alur sadap kemungkinan disebabkan ketahanan klon IRR 39 terhadap serangan KAS. Menurut Lasminingsih (2010) bahwa salah satu kelebihan dari klon IRR 39 mempunyai ketahanan yang baik terhadap penyakit kering alur sadap dan mempunyai respons yang tergolong sedang terhadap pemakaian stimulan. 
Menurut Santoso dan Basuki (1991), secara umum sistem penyadapan yang dianjurkan harus memenuhi prinsip: (1) mudah dilaksanakan, (2) mampu menghasilkan produksi tinggi, (3) biayanya rendah, (4) menghasilkan kulit pulihan baik dan tidak mengganggu pertumbuhan tanaman, (5) persentase kekeringan alur sadap rendah, dan (6) menjamin kesinambungan siklus eksploitasi. Kesemua prinsip tersebut harus berjalan seimbang agar dicapai produktivitas sesuai potensi tanaman, sehingga total produksi satu siklus dapat tercapai. Apabila dalam pelaksanaannya terjadi ketidakseimbangan, akan berdampak negatif terhadap produktivitas, biaya produksi, dan umur ekonomi tanaman (Basuki, 1983). Oleh karena itu pelaksanaan penyadapan harus mengikuti norma yang benar, sehingga masa produktif tanaman dapat mencapai 25-30 tahun sadap (Junaidi dan Kuswanhadi, 2011).

Kekeringan alur sadap dapat terjadi sebagai akibat penyadapan yang terlalu berat. Siswanto dan Darussamin (1995) melaporkan bahwa pengambilan lateks yang berlebihan merupakan penyebab utama terjadinya kekeringan alur sadap. Penggunaan stimulan konsentrasi tinggi dengan penyadapan yang intensif, juga merupakan penyebab terjadinya kekeringan alur sadap. Gejala kekeringan alur sadap ditandai dengan mula-mula sebagian alur sadap tidak mengalirkan lateks dan sebagian lainnya masih normal, atau dapat pula ditandai dengan prakoagulasi lateks pada alur sadap.

Menurut Budiman dan Kuswanhadi (1996) penyakit kering alur sadap merupakan gangguan fisiologis pada tanaman karet, bukan disebabkan oleh organisme hidup. Penyakit ini terjadi karena tidak seimbang antara lateks yang dipanen dengan lateks yang terbentuk kembali, akibat eksploitasi yang terlalu berat yang melebihi kapasitas tanaman. Pengamatan morfologi dan histologi terhadap tanaman karet yang terserang KAS terlihat pada jaringan kulit batang terjadi pembentukan sel tilosoid di dalam pembuluh lateks sebagai akibat penyimpangan proses fisiologi, sehingga menyebabkan gangguan pembentukan butir-butir lateks (Jacob dan Prevot, 1989; Gomez et al., 1990).

\section{KESIMPULAN}

Klon IRR 39 tergolong ke dalam kelompok klon penghasil lateks kayu dengan produksi awal rendah. Salah satu upaya yang dapat dilakukan untuk mengatasi kelemahan tersebut adalah dengan memberikan perlakuan stimulan sejak awal penyadapan. Pemberian stimulan sejak awal

Tabe1 3. Intensitas kering alur sadap (\%)

Table 3. Intensity of tapping panel dryness (\%)

\begin{tabular}{|c|c|c|c|c|c|c|}
\hline \multirow{2}{*}{$\begin{array}{l}\text { Perlakuan } \\
\text { Treatments }\end{array}$} & \multicolumn{6}{|c|}{$\begin{array}{c}\text { Kering alur sadap } \\
\text { Tapping panel dryness }\end{array}$} \\
\hline & Normal & $1-5(\mathrm{~cm})$ & $1-10(\mathrm{~cm})$ & $1-20(\mathrm{~cm})$ & $1-40(\mathrm{~cm})$ & Kering total \\
\hline $\mathrm{S} 2 / \mathrm{d} 3+\mathrm{E} 2 \%$ & $14(47)$ & (23) & $5 \quad(17)$ & $1 \quad(3)$ & $0 \quad(0)$ & 3 (10) \\
\hline $\mathrm{S} / 2 \mathrm{~d} 4+\mathrm{E} 2 \%$ & $16(53)$ & $5 \quad(17)$ & 3 (10) & $2 \quad(7)$ & 1 (3) & 3 (10) \\
\hline $\mathrm{S} / 2 \mathrm{~d} 3+\mathrm{E} 2,5 \%$ & $15(50)$ & $(17)$ & $5 \quad(17)$ & $1 \quad(3)$ & 1 (3) & 3 (10) \\
\hline $\mathrm{S} / 2 \mathrm{~d} 4+\mathrm{E} 2,5 \%$ & $14(47)$ & (23) & 3 (10) & $2 \quad(7)$ & $2(7)$ & 4 (14) \\
\hline Kontrol (S/2d3) & $15(50)$ & (23) & $5 \quad(17)$ & $\begin{array}{ll}0 & (0)\end{array}$ & 1 (3) & $2 \quad(7)$ \\
\hline
\end{tabular}

Jumlah sampel 30 tanaman pohon per perlakuan (Number of sample is 30 plants per treatment)

- Angka di antara kurung merupakan persentase kering alur sadap (Number in parentheses is the percentage of tapping panel dryness)

- $\mathrm{S} / 2 \mathrm{~d} 3=$ Penyadapan setengah spiral disadap setiap tiga hari sekali $(\mathrm{S} / 2 \mathrm{~d} 3$ = half spiral tapping for every three day)

- $\mathrm{S} / 2 \mathrm{~d} 4$ = Penyadapan setengah spiral disadap setiap empat hari sekali $(\mathrm{S} / 2 d 4$ = half spiral tapping for every four day)

- $\mathrm{E}=$ ethrel 
penyadapan terbukti dapat meningkatkan produksi (g/p/s) sebanyak 164-181\% dibandingkan kontrol. Perlakuan $\mathrm{S} / 2 \mathrm{~d} 4+$ Ethrel 2\% dan S/2 d4 + Ethrel 2,5\% menghasilkan produksi $(\mathrm{kg} / \mathrm{ha} / \mathrm{th})$ lebih rendah karena jumlah hari sadap yang lebih sedikit dibandingkan kontrol. Peningkatan produksi karet kering $(\mathrm{kg} / \mathrm{ha} / \mathrm{th})$ selama 7 tahun pengamatan terdapat pada perlakuan $\mathrm{S} / 2 \mathrm{~d} 3+$ Ethrel 2,5\% (136\% terhadap kontrol) dan S/2 d3 + Ethrel 2\% (123\% terhadap kontrol). Perlakuan S/2 d3 + Ethrel $2,5 \%$ memberikan hasil lebih tinggi dibandingkan dengan perlakuan lainnya.

Penggunaan stimulan sejak awal sadap pada klon IRR 39 ternyata tidak berpengaruh negatif terhadap pertumbuhan lilit batang, pertumbuhan kulit pulihan, KKK, dan kekeringan alur sadap.

\section{DAFTAR PUSTAKA}

Aidi-Daslin. 2005. Kemajuan pemuliaan dan seleksi dalam menghasilkan kultivar karet unggul. Prosiding Lokakarya Nasional. Pemuliaan Tanaman Karet 2005, Medan, 22-23 November, 2005. Balai Penelitian Sungei Putih Pusat Penelitian Karet. 26-37.

Anwar, C. 2012. Prospek Karet Masih Bagus. Media Perkebunan, Edisi 106, November 2012, 68-69.

Azwar, R. dan I. Suhendry. 1998. Kemajuan pemuliaan karet dan dampaknya terhadap peningkatan produktivitas. Prosiding Lokakarya Nasional. Pemuliaan Karet 1998 dan Diskusi Nasional Prospek Karet Alam Abad 21, 1998, Medan, 8-9 Desember 1998. Pusat Penelitian Karet Asosiasi Penelitian Perkebunan Indonesia. 5164.

Basuki, R. dan P. Lubis. 1973. Percobaan stimulasi ethrel di Sumatera Utara oleh RRC Tanjung Morawa. Menara Perkebunan, 41(2), 55-62.
Basuki dan H.P.L. Tobing. 1980. Penyadapan dengan berbagai panjang alur sadap dan stimulan ethepon sejak bukaan sadap pertama. Prosiding Lokakarya Karet 1980. Pusat Penelitian Karet Tanjung Morawa, 2425 Juni 1980, 95- 108.

Basuki. 1983. Masalah utama dalam eksploitasi karet. Disampaikan dalam Pertemuan Teknis Karet P4TMPN/PTP Wilayah I, 28 Desember 1983. Berita P4TM.

Boatman, S.G. 1968. Preliminary physiological studies on the promotion of latex flow by plant growth regulators. J. Rubb. Res. Inst. Malaya 19(5): 243258.

Budiman, A. dan Kuswanhadi. 1996. Penanggulangan kering alur sadap pada beberapa klon karet anjuran. Warta Pusat Penelitian Karet 15(3): 176-183.

Gohet, E., J.E, Prevot, J.M. Eschbach, A. Clement, and J.L. Jacob. 1996. Clone croissance et stimulation, facteurs de la production de latex. Plantations, recherché, developpement, 30-38.

Gomez, J.B., S. Hamzah, H. Chandimathi, and L.H. Ho. 1990. Brown bast syndrome of Hevea. Part II: Histoligical Observations. J. Nat. Rubb. Res., 5(2): 90-101.

International Rubber Study Group. 2005. The World Rubber Industry. IRSG, November 2005.

Jacob, J.L. and J.C. Prevot. 1989. Bark dryness: Histological, cytological, and biochemical aspects. IRCA-CIRADFrance. Proc. IRRDB Workshop on the Tree Dryness. Penang, 20-32.

Junaidi, U., Kuswanhadi, dan A. Tjasadihardja. 1995. Respons klon karet anjuran terhadap berbagai sistem sadap. Prosiding Lokakarya Nasional Pemuliaan Karet, Medan, 2930 November 1995. Pusat Penelitian Karet. 201-214. 
Junaidi, U. dan Kuswanhadi. 1998. Optimasi produktivitas klon melalui sistem eksploitasi. Prosiding Lokakarya Nasional. Pemuliaan Karet dan Diskusi Nasional Prospek Karet Alam Abad 21, 1998, Medan, 8-9 Desember 1998. Pusat Penelitian Karet Asosiasi Penelitian Perkebunan Indonesia. 236-245.

Junaidi, U. dan Kuswanhadi. 2011. Penyadapan. Saptabina Usahatani Karet Rakyat (Ed kelima). Balai Penelitian Sembawa-Pusat Penelitian Karet.

Karyudi dan Lukman. 1985. Pemakaian ethepon dalam eksploitasi tanaman karet. Warta Perkaretan 4(1): 19-22.

Lasminingsih, M., G. Wibawa, I. Boerhendhy, dan A. Suhaimi. 1998. Evaluasi Klon Penghasil Lateks-Kayu dan Integrasi Tanaman Kehutanan pada Perkebunan. Prosiding Lokakrya Nasional. Pemuliaan Karet 1998 dan Diskusi Nasional Prospek Karet Alam Abad 21, 1998, Medan, 8-9 Desember 1998. Pusat Penelitian Karet Asosiasi Penelitian Perkebunan Indonesia. 7388.

Lasminingsih, Muji. 2010. Rekomendasi klon karet periode 2010-2014. Seri Leaflet No 01/Klon/LF/2010. Balai Penelitian Sembawa, Pusat Penelitian Karet.

Lukman. 1979. Pembukaan sadapan dan stimulasi sehubungan dengan besarnya lilit batang. Laporan Tahun Pertama. Bulletin. BPP Medan 10(3): 123-143.

Pusat Penelitian Karet. 1993. Hasil Rumusan Lokakarya Nasional Pemuliaan Tanaman Karet 1992. Monografi Penelitian dan Pengembangan Karet, No.1.

Santoso, B. dan Basuki. 1991. Manajemen panen tanaman karet di perkebunan. Lokakarya Karet. Medan, 2-4 Juli 1991. Pusat Penelitian Karet Sei Putih dan P4TM.
Siagian, N.L. dan Harahap. 1975. Stimulasi ethrel pada alur sadap dalam praktek di P.N. Perkebunan V. Menara Perkebunan 43(6): 275-284.

Siregar, M., Basuki, dan Parlindungan Lubis. 1973. Stimulasi ethrel pada kulit perawan. Risalah Rapat Teknis Eksploitasi Karet BPP Medan. Rubb. Rs. Centre Tanjung Morawa, p11.

Siswanto dan A. Darussamin. 1995. Deteksi dan penanggulangan penyebaran TPD pada perkebunan karet. Warta Puslit Biotek Perkebunan, 1(1), 10-14.

Sivakumaran, S.S.W. Pakianathan, and P.D. Abraham. 1984. Continous yield stimulation-plausible cause for yield decline. J. Rub. Res. Inst. Malay 32(2): 119-143.

Southorn, W.A. 1969. Physiology of Hevea (latex flow). J. Rubb. Res. Inst. Malaya, 21(4), 494-512.

Sumarmadji, 2000. Sistem eksploitasi tanaman karet yang spesifik diskriminatif. Warta Pusat Penelitian Karet 19(1-3): 31-39.

Sumarmadji. 2009. Paket teknologi sistem eksploitasi untuk meningkatkan produktivitas tanaman karet. Pros. Pertemuan Teknis Eksploitasi Tanaman Karet, Medan, 1-2 Desember 2009. Balai Penelitian Sungei Putih.

Sumarno-Kartowardojo, Amir Sube, Nur Mansjoeriah, Tata Surdiah, dan AminTjasadihardja. 1976. Beberapa pengaruh stimulasi ethrel terhadap sifat lateks karet alam. Menara Perkebunan 44(2): 75-81.

Webster, C.C. and W.J. Baulkwill. 1989. Rubber. Longman Sci. \& Tech., John Wiley \& Sons, Inc., New York. 614p.

Woelan, S., Aidi-Daslin, I. Suhendry, dan M. Lasminingsih. 2005. Evaluasi keragaan klon karet IRR seri 100 dan 200. Pros. Lok. Nas. Pemuliaan Tanaman Karet 2005. Medan, 22-23 November 2005. Balai Penelitian Sungei Putih Pusat Penelitian Karet. 